Legacy content

\title{
Substantial addition to ARD Online
}

\section{J O'Flaherty, L van de Putte}

\section{Annals content from 1939 now available online}

5 r

rom June 2007 the complete archive

of Annals of the Rheumatic Diseases - the

Eular journal will be available online www.ard.bmj.com - that's all issues from January 1939 to today. In keeping with the BMJ Group's delayed free access policy all content older than 12 month's is free to non-subscribers, including the newly digitised legacy content.

ARD was the first international rheumatology journal in English, so it attracted prominent authors, and their papers gave the first global mirror of rheumatology in Europe and North America as long ago as 1939. Interestingly, in the very first issue of the journal 6 of the 10 papers were about infections in relation to rheumatism. Other noteworthy articles include an authoritative overview of rheumatic diseases by Philip Hench - to date the only Nobel Prize winner in the field of rheumatology, Ludwig Aschoff's paper on rheumatic nodules in the heart and W S Tegner's paper on the treatment of the rheumatic diseases in the United States and Europe, even in the light of today's rheumatology, a highly interesting travel report.

The legacy content is an immense addition to an already rich site. ${ }^{1}$ As well as being able to search and browse the complete Annals archive you can:

- Link to the full text of cited references of all journals hosted by HighWire
Press $^{2}$ including the New England Journal of Medicine, Annals of Internal Medicine, and JAMA

- Save searches and articles in personal folders (requires free registration)

- Find related articles in ARD and PubMed

- Find web only material for selected articles, eg, additional references and tables

- Receive customised alerts, eg, when new content is published or a specific article is cited (requires free registration)

- Download articles to citation manager

- Download figures as PowerPoint slides for use in teaching

- Respond to articles using the eLetter facility

\section{MORE FEATURES}

The Annals is one of the world's leading rheumatology journals with an impact factor of 6.956 and global reach. Each print issue is sent to approximately 10000 subscribers and there are about 100000 visitors to ARD Online each month. The journal attracts world class research and the high rejection rate ensures only the best is published.

- ARD offers fast peer review with a median time to first decision of just 5 weeks using online submission and review $^{3}$
- ARD Online First ${ }^{4}$ gets research into the public domain within 2 weeks of acceptance - and indexed by PubMed a few days later

- The Unlocked option ${ }^{5}$ allows authors to make papers free from the point of publication

- Authors retain copyright and have liberal rights of reuse without permission, they also receive a royalty of large commercial reprint sales ${ }^{6}$

- Our active press release programme helps get selected research to a very wide international audience

\section{ACKNOWLEDGEMENTS}

BMJ Group and Eular thank the US National Library of Medicine who digitised the articles from 1939 to 1996 free of charge - in return ARD articles will be published on PubMedCentral ${ }^{7}$ (with a 3 year embargo).

Ann Rheum Dis 2007;66:852.

doi: 10.1136/ard.2007.076489

\section{Authors' affiliations}

Janet O'Flaherty, Managing Editor ARD;

joflaherty@bmigroup.com

Leo van de Putte, Editor ARD;

ARD@bmigroup.com

Important notice: If you or your institution do not subscribe to ARD you will need to complete a free, one time registration to access this legacy content. This registration will also allow you to access the legacy content of other BMJ Journals (www.journals.bmj.com) as this is made available during 2007. Individuals who receive the Annals through attendance at the annual Eular congress do NOT need to register.

\section{REFERENCES}

1 http://journals.bmj.com/lrc/bmjusersguide.pdf

2 http://highwire.stanford.edu/

3 http://submit-ard.bmj.com/

4 http://ard.bmi.com/onlinefirst.dt

5 http://ard.bmi.com/info/unlocked.dt

6 http://ard.bmi.com/ifora/licence.dtl

7 http://www.pubmedcentral.nih.gov 